prolonged treatment secondary changes such as fluid retention may necessitate increments in the daily dose in resistant cases.

It has been suggested that a combination of hypotensive agents given in low dose is a useful way to reduce high blood pressure. ${ }^{16}$ Nevertheless, the response to D was related to its plasma concentration. A poor response was associated with extensive metabolism of the drug and was overcome by increasing the dose rather than by adding other hypotensive agents to the therapeutic regimen. This is important since compliance may fall as a result of using several drugs. ${ }^{17}$

Dr J H Silas is in receipt of a grant from Roche Products Limited, Welwyn Garden City, Hertfordshire.

\section{References}

${ }^{1}$ Buhler, F R, et al, New England fournal of Medicine, 1972, 278, 1209.
2 Louis, W J, Doyle, A E, and Anavekar, S, New England fournal of Medicine, 1973, 288, 599.

3 Sjoerdsma, A, Circulation Research, 1967, 21, suppl No 3, p 119.

${ }^{4}$ Morgan, T D, et al, British fournal of Clinical Pharmacology, 1975, 2, 159.

5 Angelo, M, et al, British fournal of Pharmacology, 1975, 55, 264.

${ }^{6}$ Lennard, M S, et al, fournal of Chromatography, 1977, 133, 161.

7 Malcolm, S L, and Marten, T R, Analytical Chemistry, 1976, 48, 807.

8 Cohen, E L, fournal of Laboratory and Clinical Medicine, 1971, 77, 1205

9 Townshend, M M, and Smith, A J, Clinical Science and Molecular Medicine, 1973, 44, 253.

${ }_{10}$ Angelo, M, et al, Biochemical Society Transactions, 1976, 4, 704.

${ }_{11}$ Kitchen, A H, and Turner, R W D, British Medical fournal, 1966, 2, 728.

12 Allen, J G, et al, Drug Metabolism and Disposition, 1975, 3, 332.

13 Allen, J G, Brown, A N, and Marten, T R, Xenobiotica, 1976, 6, 405.

14 Dunstan, H P, Tarazi, R C, and Bravo, E L, New England fournal of Medicine, 1972, 286, 861.

15 Sandler, G, Leishman, A W D, and Humberstone, P J, Circulation, 1968, 38, 542.

16 Petrie, J C, et al, British Medical fournal, 1976, 3, 137.

17 Weintraub, M, Au, W, and Lasagna, L, fournal of the American Medical Association, 1973, 224, 481.

\title{
Recurrent breast cancer treated with the antioestrogen tamoxifen: correlation between hormonal changes and clinical course
}

\author{
K J WILLIS, D R LONDON, H W C WARD, W R BUTT, S S LYNCH, B T RUDD
}

British Medical fournal, 1977, 1, 425-428

\section{Summary}

Forty-five post-menopausal women with recurrent breast cancer were treated with the antioestrogen, tamoxifen, $20 \mathrm{mg}$ twice daily. Clinical assessment after 12 weeks indicated that $18(40 \%)$ showed some remission. Gonadotrophins were suppressed within two weeks to relatively constant concentrations within the post-menopausal range, responses to luteinising hormone-releasing hormone (LH-RH) did not change, and androgen concentrations remained within the normal range in all patients. Oestradiol concentrations rose steadily only in women in whom treatment failed. Serum prolactin concentrations were raised in 18 out of the $44(41 \%)$ patients in whom they were measured; 13 of these did not respond to treatment. Treatment did not change the average prolactin concentration when this was within the normal range, but it significantly reduced prolactin concentrations in hyperprolactinaemic patients-within two

\section{Queen Elizabeth Hospital, Birmingham B15 2TH}

K J WILLIS, MB, MRCP, research fellow (present address: Imperial Cancer Research Fund, Department of Medical Oncology, St Bartholomew's Hospital, London)

D R LONDON, DM, FRCP, consultant physician

$\mathrm{H}$ W C WARD, FRCR, MRCP, consultant radiotherapist (now Professor and Chief, Department of Radiation Oncology, South Western Medical School, University of Texas, Dallas)

Department of Clinical Endocrinology, Birmingham and Midland Hospital for Women, Birmingham B11 4HL.

W R BUTT, DSC, FRIC, professor of endocrinology

S S LYNCH, PHD, principal biochemist

B T RUDD, PHD, principal biochemist weeks $(P<0.01)$ in those who responded well and by six weeks $(P<0.05)$ in those who showed no remission. Among patients with normal prolactin values the release of prolactin after thyrotrophin-releasing hormone was significantly greater in those with no remission than in those who responded to tamoxifen. Responses in those with hyperprolactinaemia were reduced to about half the control values, and again this change occurred faster in those who were successfully treated. Patients therefore seem to have a better chance of responding to antioestrogen treatment if prolactin secretion is low.

\section{Introduction}

Breast cancer is the commonest malignancy to affect European and American women, and considerable efforts have been made to understand its pathogenesis and improve treatment. Hormonal manipulation has been tried for palliating inoperable disease. The endocrine glands have been surgically ablated, ${ }^{1-3}$ and corticosteroids have been administered. ${ }^{4}$ Both methods may produce remissions in about a third of patients ${ }^{5-7}$ but there is no reliable way of predicting who will respond. Bulbrook, ${ }^{8}$ for example, derived a discriminant function but its predictive value is affected by many factors, including age, obesity, menopausal status, and drugs. ${ }^{910}$

Specific oestrogen receptors have been recognised in some breast tumours. ${ }^{112}$ Since antioestrogens ${ }^{13}$ compete for binding with oestrogen at target sites ${ }^{14}$ a trial of such compounds in the treatment of breast cancer is indicated. The antioestrogen tamoxifen (Nolvadex) ${ }^{15}$ has been well tolerated by patients with inoperable breast cancer and has produced some clinical improvement. ${ }^{16} 17$

There have been few studies of the hormonal changes produced by tamoxifen in patients with breast cancer. ${ }^{18} 19 \mathrm{We}$ determined its effects on pituitary and steroid hormones in postmenopausal patients with recurrent breast cancer and 
correlated any hormonal changes with the clinical course of the disease. In this way we hoped to define any hormonal differences between patients that would be useful in planning treatment.

\section{Patients and methods}

Forty-five post-menopausal women with recurrent breast cancer were investigated. They had received no treatment for three months before the trial, were taking no drugs likely to affect hormone concentrations, and had received no ablative endocrine treatment. The women were examined for evidence of local tumour as well as distant spread. The size of palpable tumour masses such as lymph nodes and skin nodules was measured in two planes at right angles, and the assessments were based on the product of these values.

Endocrine tests were then carried out. On the first day patients received luteinising hormone-releasing hormone (LH-RH; $100 \mu \mathrm{g})^{20}$ at 0 minutes, and venous blood samples were taken at $-15,0,+30$, and +60 minutes for hormone assays. Gonadotrophins released after $\mathrm{LH}-\mathrm{RH}$ were expressed as the sum of the incremental values obtained by subtracting the basal value from concentrations at 30 and 60 minutes. On the second day thyrotrophin-releasing hormone (TRH; $200 \mu \mathrm{g}$ ) was administered at 0 minutes. Blood samples were obtained at $-15,0,+15$, and +30 minutes for prolactin determinations. The response to TRH was expressed as the sum of the incremental values at 30 and 60 minutes.

When these investigations were completed the patients started tamoxifen $20 \mathrm{mg}$ twice daily. Physical examinations and endocrine tests were then repeated after two, six, and 12 weeks of treatment. Treatment was considered a success when at least half the lesions reduced in size by $50 \%$ or more and no new lesions had occurred at 12 weeks. Patients whose disease progressed or remained static after 12 weeks were classified as treatment failures. When lesions advanced rapidly before 12 weeks tamoxifen was stopped and the patient was given other treatment. Thirty-six of the 45 patients completed the course.

\section{LABORATORY METHODS}

Immunoreactive $\mathrm{LH}$ and follicle-stimulating hormone (FSH) were determined in the serum samples by double antibody radioimmunoassays $^{20}$ and results were expressed in terms of units MRC 69/104.

Prolactin was determined by a double antibody radioimmunoassay. ${ }^{21}$ The antigen for labelling was NIH V-L-S 2 and the antibody was kindly provided by Dr G V Groom (Cardiff). Results were expressed as $\mathrm{mU} / 1 \mathrm{MRC} 71 / 222$. Because of pulsatile fluctuations and the possible effect of stress on prolactin secretion, determinations were made on two samples taken at 15-minute intervals from an indwelling catheter. Repeated estimations were made 24 hours later on 25 of the patients. The coefficient of variation for the pairs of results within the normal range was $10 \%$. The lower result in each pair was used for analysis. The normal range was calculated from results obtained in 46 postmenopausal women aged 43-70 years who had no breast cancer and were taking no drugs. One was found to be hyperprolactinaemic $(860 \mathrm{mU} / \mathrm{l})$ and was excluded from the calculation of the normal range. In the remaining 45 the mean ( $\pm 2 \mathrm{SD}$ ) was $230(90-370) \mathrm{mU} / \mathrm{l}$, which is similar to the range reported by Vekemans and Robyn. ${ }^{22}$ Oestradiol and androgens (testosterone and androstenediol) were measured by radioimmunoassays as described.$^{2023}$

The results were analysed statistically by Student's $t$ test, analysis of variance, and Wilcoxon's rank sum tests when appropriate. Basal values for most hormones were determined in each of the 45 patients. The effects of treatment were analysed from results obtained in the 36 patients who completed the 12 -week course.

\section{Results}

Clinical assessment-At 12 weeks treatment was considered a success in $18(40 \%)$ of the 45 patients.

Gonadotrophins-There were no significant differences in the mean pretreatment serum LH and FSH values between the patients who subsequently showed remission and those in whom treatment failed (table I). Treatment with tamoxifen significantly decreased $(\mathbf{P}<0.001)$ both hormones by the second week, and this effect was maintained until the 12-week assessment. The effects were similar in the two groups of patients. Responses to $\mathrm{LH}-\mathrm{RH}$ were similar in both groups of patients and treatment with tamoxifen produced no significant changes in response in either group (table I).

Oestradiol-Mean values before treatment were not significantly different in the two groups. Seven patients (three with remission and four without) had values above the normal range expected for the method $(300 \mathrm{pmol} / 1(81.7 \mathrm{pg} / \mathrm{ml}))$ before treatment but they fell to within the normal range after two weeks' treatment. There was no overall change in oestradiol values in the group with remission, but there was a highly significant linear increase with treatment in those who had no remission, and the value reached by 12 weeks $(294 \pm 45$ $\mathrm{pmol} / \mathrm{l}(80 \cdot 1 \pm 12 \cdot 3 \mathrm{pg} / \mathrm{ml}))$ was significantly higher than the basal value $(193 \pm 34 \mathrm{pmol} / \mathrm{l}(52 \cdot 6 \pm 9 \cdot 3 \mathrm{pg} / \mathrm{ml}) ; \mathrm{P}<0 \cdot 01)$ (table I).

Androgens-Before treatment basal androgen values were within the normal range for postmenopausal women and there were no significant differences between the treatment groups. Tamoxifen had no effect (table I).

Basal prolactin values-Eighteen of the 44 women in whom results were available had basal prolactin values above the normal postmenopausal range (table II). Only two women with tamoxifen-induced remission remained hyperprolactinaemic after six weeks' treatment

TABLE II-Incidence (\%) of hyperprolactinaemia before and during treatment with tamoxifen. Figures in parentheses show how many patients had hyperprolactinaemia out of number studied

\begin{tabular}{|c|c|c|c|c|}
\hline \multirow{2}{*}{ Treatment } & \multicolumn{4}{|c|}{ Tamoxifen treatment } \\
\hline & Before & 2 Weeks & 6 Weeks & 12 Weeks \\
\hline $\begin{array}{l}\text { Successful } \\
\text { Unsuccessful }\end{array}$ & $\begin{array}{l}29(5 / 17) \\
48(13 / 27)\end{array}$ & $\begin{array}{r}6(1 / 17) \\
35(9 / 26)\end{array}$ & $\begin{array}{l}12(2 / 17) \\
39(9 / 23)\end{array}$ & $\begin{array}{r}6(1 / 17) \\
12(2 / 17)^{*}\end{array}$ \\
\hline
\end{tabular}

*Five patients with continuing hyperprolactinaemia had been put on to other *Five patients with continuing hyperprola
treatment before the 12 -week assessment.

TABLE I-Mean hormonal values ( $\pm S E$ of mean) during treatment with tamoxifen

\begin{tabular}{|c|c|c|c|c|c|c|c|c|}
\hline & \multirow{2}{*}{$\begin{array}{l}\text { Total No of } \\
\text { subjects }\end{array}$} & \multirow{2}{*}{$\begin{array}{l}\text { Basal } \\
\text { value }\end{array}$} & \multicolumn{5}{|c|}{ Patients completing 12-week trial } & \multirow{2}{*}{$\begin{array}{l}\text { Treatment: } \\
\text { success or } \\
\text { failure }\end{array}$} \\
\hline & & & No of patients & Basal & 2 Weeks & 6 Weeks & 12 Weeks & \\
\hline $\begin{array}{l}\text { Basal gonadotrophins: } \\
\text { LH }(U / 1)\end{array}$ & $\begin{array}{l}18 \\
27\end{array}$ & $\begin{array}{l}20 \cdot 4 \pm 1 \cdot 6 \\
21 \cdot 7 \pm 2 \cdot 6\end{array}$ & $\begin{array}{l}18 \\
18\end{array}$ & $\begin{array}{l}20 \cdot 4 \pm 1 \cdot 6 \\
22 \cdot 4 \pm 2 \cdot 6\end{array}$ & $\begin{array}{l}12 \cdot 6 \pm 1 \cdot 3 \ddagger \\
14 \cdot 8 \pm 1 \cdot 9 \ddagger\end{array}$ & $\begin{array}{l}13 \cdot 2 \pm 1 \cdot 6 \ddagger \\
12 \cdot 0 \pm 1 \cdot 6 \pm\end{array}$ & $\begin{array}{l}13 \cdot 4 \pm 1 \cdot 7 \ddagger \\
11 \cdot 5 \pm 1 \cdot 6 \ddagger\end{array}$ & $\begin{array}{l}\text { Success } \\
\text { Failure }\end{array}$ \\
\hline FSH $(U / 1)$ & $\begin{array}{l}17 \\
26\end{array}$ & $\begin{array}{l}57 \cdot 0 \pm 4 \cdot 0 \\
61 \cdot 0 \pm 5 \cdot 1\end{array}$ & $\begin{array}{l}17 \\
18\end{array}$ & $\begin{array}{l}57 \cdot 0 \pm 4 \cdot 0 \\
61 \cdot 5 \pm 6 \cdot 6\end{array}$ & $\begin{array}{l}38 \cdot 8 \pm 2 \cdot 4 \ddagger \\
47 \cdot 5 \pm 5 \cdot 3 \ddagger\end{array}$ & $\begin{array}{l}41 \cdot 2 \pm 3 \cdot 0 \ddagger \\
43 \cdot 1 \pm 5 \cdot 2 \ddagger\end{array}$ & $\begin{array}{l}36 \cdot 6 \pm 3 \cdot 0 \ddagger \\
37 \cdot 4 \pm 5 \cdot 6 \ddagger\end{array}$ & $\begin{array}{l}\text { Success } \\
\text { Failure }\end{array}$ \\
\hline $\begin{array}{l}\text { LH-RH tests (total increments: } \\
\text { LH (U/l) }\end{array}$ & $\begin{array}{l}18 \\
26\end{array}$ & $\begin{array}{l}82 \cdot 8 \pm 9 \cdot 3 \\
85 \cdot 6 \pm 6 \cdot 9\end{array}$ & $\begin{array}{l}16 \\
17\end{array}$ & $\begin{array}{l}78 \cdot 9 \pm 9 \cdot 4 \\
91 \cdot 6 \pm 9 \cdot 1\end{array}$ & $\begin{array}{l}75 \cdot 1 \pm 7 \cdot 5 \\
82 \cdot 7 \pm 8 \cdot 7\end{array}$ & $\begin{array}{l}78 \cdot 9 \pm 7 \cdot 5 \\
76 \cdot 9 \pm 8 \cdot 6\end{array}$ & $\begin{array}{l}81 \cdot 4 \pm 8.3 \\
79 \cdot 6 \pm 7.9\end{array}$ & $\begin{array}{l}\text { Success } \\
\text { Failure }\end{array}$ \\
\hline FSH $(U / 1)$ & $\begin{array}{l}17 \\
26\end{array}$ & $\begin{array}{l}49 \cdot 9 \pm 7 \cdot 6 \\
46 \cdot 3 \pm 4 \cdot 9\end{array}$ & $\begin{array}{l}14 \\
16\end{array}$ & $\begin{array}{l}45 \cdot 5 \pm 8 \cdot 1 \\
52 \cdot 0 \pm 5 \cdot 7\end{array}$ & $\begin{array}{l}34 \cdot 1 \pm 6 \cdot 9 \\
44 \cdot 2 \pm 6 \cdot 6\end{array}$ & $\begin{array}{l}40 \cdot 5 \pm 6 \cdot 7 \\
44 \cdot 1 \pm 7 \cdot 8\end{array}$ & $\begin{array}{l}45 \cdot 2 \pm 7 \cdot 1 \\
41 \cdot 0 \pm 6 \cdot 3\end{array}$ & $\begin{array}{l}\text { Success } \\
\text { Failure }\end{array}$ \\
\hline $\begin{array}{l}\text { Basal gonadal steroids: } \\
\text { Oestradiol (pmol/l) }\end{array}$ & $\begin{array}{l}18 \\
26\end{array}$ & $\begin{array}{l}211 \pm 34 \\
186 \pm 26\end{array}$ & $\begin{array}{l}17 \\
18\end{array}$ & $\begin{array}{l}216 \pm 34 \\
193 \pm 34\end{array}$ & $\begin{array}{l}210 \pm 42 \\
248 \pm 30\end{array}$ & $\begin{array}{l}200 \pm 39 \\
249 \pm 27\end{array}$ & $\begin{array}{l}246 \pm 32 \\
294 \pm 45 \dagger\end{array}$ & $\begin{array}{l}\text { Success } \\
\text { Failure }\end{array}$ \\
\hline Androgens (nmol/l) & $\begin{array}{l}18 \\
26\end{array}$ & $\begin{array}{l}3 \cdot 8 \pm 0 \cdot 35 \\
3 \cdot 2 \pm 0 \cdot 29\end{array}$ & $\begin{array}{l}17 \\
18\end{array}$ & $\begin{array}{l}3.9 \pm 0.35 \\
3.5 \pm 0.39\end{array}$ & $\begin{array}{l}4 \cdot 4 \pm 0 \cdot 52 \\
4 \cdot 0 \pm 0 \cdot 41\end{array}$ & $\begin{array}{l}4 \cdot 2 \pm 0 \cdot 30 \\
3 \cdot 7 \pm 0 \cdot 31\end{array}$ & $\begin{array}{l}4 \cdot 5 \pm 0 \cdot 50 \\
4 \cdot 3 \pm 0 \cdot 45\end{array}$ & $\begin{array}{l}\text { Success } \\
\text { Failure }\end{array}$ \\
\hline
\end{tabular}


TABLE III-Serum prolactin (mean $\pm S E$ of mean) and response to TRH (mean sum of increments $\pm S E$ of mean) during tamoxifen treatment

\begin{tabular}{|c|c|c|c|c|c|c|c|c|c|c|}
\hline & \multicolumn{5}{|c|}{ Patients who responded to treatment } & \multicolumn{5}{|c|}{ Patients who did not respond to treatment } \\
\hline & $\begin{array}{c}\text { No of } \\
\text { patients }\end{array}$ & Basal & $\stackrel{2}{2}$ & $\begin{array}{c}6 \\
\text { Weeks }\end{array}$ & $\begin{array}{c}12 \\
\text { Weeks }\end{array}$ & $\begin{array}{c}\text { No of } \\
\text { patients }\end{array}$ & Basal & $\stackrel{2}{2}$ & $\begin{array}{l}6 \\
\text { Weeks }\end{array}$ & $\begin{array}{c}12 \\
\text { Weeks }\end{array}$ \\
\hline \multicolumn{11}{|c|}{ Basal prolactin } \\
\hline $\begin{array}{l}\text { Normal basal values } \\
\text { Hyperprolactinaemia }\end{array}$ & $\begin{array}{r}12 \\
5\end{array}$ & $\begin{array}{l}249=25 \\
608 \pm 167\end{array}$ & $\begin{array}{l}278 \pm 31 \\
280 \pm 48+\end{array}$ & $\begin{array}{l}231 \pm 20 \\
398 \pm 93\end{array}$ & $\begin{array}{l}232 \pm 26 \\
190 \pm 39 \pm\end{array}$ & $\begin{array}{r}10 \\
7\end{array}$ & $\begin{array}{l}259 \pm 17 \\
699 \pm 121\end{array}$ & $\begin{array}{l}255 \pm 21 \\
634 \pm 121\end{array}$ & $\begin{array}{l}225 \pm 15 \\
470 \pm 65^{*}\end{array}$ & $\begin{array}{l}223 \pm 31 \\
233 \pm 43 t\end{array}$ \\
\hline \multicolumn{11}{|c|}{ Response to TRH } \\
\hline $\begin{array}{l}\text { Normal basal prolactin } \\
\text { Hyperprolactinaemia }\end{array}$ & $\begin{array}{r}12 \\
5\end{array}$ & $\begin{array}{l}2410 \div 226 \\
4366 \pm 1179\end{array}$ & $\begin{array}{l}1846 \div 170^{+} \\
2286 \div 367^{\dagger}\end{array}$ & $\begin{array}{l}1844+184 \dagger \\
2410 \div 131\end{array}$ & $\begin{array}{l}1858 \pm 184{ }^{\dagger} \\
2330 \pm 156 \dagger\end{array}$ & $\begin{array}{r}10 \\
7\end{array}$ & $\begin{array}{l}2907 \pm 330 \\
5839 \pm 567\end{array}$ & $\begin{array}{l}2354 \pm 342 \\
4447 \pm 790\end{array}$ & $\begin{array}{l}2420 \pm 411 \\
3566 \pm 428\end{array}$ & $\begin{array}{l}2958 \pm 790 \\
2650 \pm 211 \pm\end{array}$ \\
\hline
\end{tabular}

Significance of change from basal: ${ }^{*} \mathrm{P}<0.05 ; \uparrow \mathrm{P}<0.01 ;{ }_{\dagger} \mathrm{P}<0.001$.

and only one after 12 weeks. There was a significant reduction in the mean value by the second week $(P<0.01$; table III). Nine of the 13 in whom treatment failed, however, remained hyperprolactinaemic until the sixth week, when the first significant reduction in the mean value occuired $(P<0.05 ;$ table III). Treatment was changed before the 12th week because the condition of five of these patients had deteriorated. Two of those who continued treatment until the 12th week remained hyperprolactinaemic. Treatment had no significant effect on the average amount of prolactin secreted in patients of either group who had normal basal values (table III).

Prolactin response to TRH-There was a positive correlation between the amount of prolactin released and the basal levels of prolactin $(\mathrm{r}=0.59 ; \mathrm{P}<0.001)$. The TRH responses to patients with normal basal prolactin values and responses in those with hyperprolactinaemia were therefore considered separately (table III). The TRH responses among patients with normal prolactin values were greater in those who did not respond to tamoxifen than in those who did respond to tamoxifen throughout the 12 weeks $(P<0.001)$. There was a significant reduction $\left(P<0.01 ; 23^{\circ}\right)$ in the average response by two weeks, and this was maintained until the end of treatment in those who achieved remission but not in those without remission. The responses of the hyperprolactinaemic patients in both treatment groups were significantly $(P<0.001)$ greater than the responses of those with normal values. In successfully treated patients tamoxifen reduced the responses to about half the pretreatment values by two weeks $(P<0.01)$ and this suppression was maintained until 12 weeks. In unsuccessfully treated patients the response was also suppressed but more gradually, and the reduction became significant only after six weeks $(P<0.05)$.

\section{Discussion}

These trials have shown that tamoxifen produced certain significant changes in hormone production. Except for prolactin and oestradiol values, however, the basal values and the changes produced by treatment were similar irrespective of whether treatment succeeded or failed.

The reduction in gonadotrophin secretion was unexpected because the drug is considered to act as an antioestrogen rather than as an oestrogen. Similar results have been reported, however, in normal postmenopausal women treated with clomiphene. ${ }^{24}$ These drugs oppose the negative feedback effect of oestrogen in young women, thereby provoking the release of gonadotrophins, but in older women oestrogen secretion is low and presumably there are no sites on the receptors controlling gonadotrophin secretion for the drugs to exert their antioestrogenic effects. In our trial there was no evidence that tamoxifen acted by suppressing pituitary responsiveness since the responses to LH-RH did not change throughout the course of treatment.

Androgens remained relatively constant within the normal menopausal range throughout the trial, but oestradiol concentrations showed more variation and gradually increased in the treatment failure group. By 12 weeks those without remission were producing on average significantly more oestradiol than those who were successfully treated. Since the patients were menopausal increased ovarian production seemed unlikely. Some breast carcinomas can synthesise oestradiol ${ }^{25}$ and those in whom treatment failed may have had a larger mass of tumour, which produced oestrogen, possibly by conversion from androgen.

Eighteen of the 44 patients $(41 \%)$ in whom basal prolactin was measured had values above the normal range for postmenopausal women, and in 13 of these tamoxifen had no success. The incidence of hyperprolactinaemia seems to be higher than has been reported elsewhere: Cole $e t{ }^{a l^{26}}$ found raised values in the follicular phase of younger women with breast cancer, and Wilson et $a l^{27}$ reported that values were raised in older women but that the increase was not significant. Ohgo et al, ${ }^{28}$ however, reported that six patients (three of whom were postmenopausal) out of 29 were hyperprolactinaemic.

Like Golder $e t a l,{ }^{18}$ we found that prolactin secretion was not changed by treatment in those patients with normal basal levels. The hyperprolactinaemic patients, however, showed considerable changes: those with tamoxifen-induced remission showed a significant reduction of more than half in the average concentration by the second week, and by the 12th week only one of the five patients originally hyperprolactinaemic remained so. The effect on those in whom treatment failed was smaller, and by the sixth week nine patients remained hyperprolactinaemic.

Differences between the treatment groups were also apparent in the TRH stimulation tests. The responses in patients with normal prolactin values who had no remission were significantly greater $(P<0.01)$ than those in patients who had remission throughout the 12 weeks. Furthermore, although the response was reduced by two weeks in the successfully treated group there was no significant change in the unsuccessfully treated group. In the hyperprolactinaemic group tamoxifen reduced the response to about half the control value by two weeks in those with remission and by 12 weeks in those without.

The changes in prolactin secretion during treatment conform with an antioestrogenic effect of tamoxifen at the central site for modulating the secretion of this hormone. Robyn and Vekemans ${ }^{29}$ showed that treatment of postmenopausal women with oestrogen increased serum prolactin concentrations, and oestrogen enhanced the prolactin response to TRH. ${ }^{30}$ The suppression noted in our trial shows the converse effect.

The treatment resulted in a remission rate of $40 \%$, which compares favourably with that in other series. Cole et $a l^{16}$ and Ward, ${ }^{17}$ using the same criteria, reported remission rates of $22 \%$ and $36 \%$ respectively using a dose of $10 \mathrm{mg}$ twice a day. Ward ${ }^{17}$ subsequently used $20 \mathrm{mg}$ twice daily and obtained remissions in $40 \%$ of women.

Our clinical impressions conform with those generally expressed about tamoxifen-namely, that it is an effective palliative in some cases of breast cancer and its lack of toxicity makes it especially acceptable to patients. Prolactin concentrations and the responses to TRH appear to offer indices that may be of some predictive value in selecting patients for treatment. Treatment will probably succeed if the prolactin concentration is within the normal range and the response to TRH not excessive.

It seems reasonable to suggest that treatment with tamoxifen may be more effective if prolactin production is controlled at the same time by treatment with a drug such as bromocriptine. Although tamoxifen may block oestrogen receptors in breast tumours, remission may also be related to the fall in serum 
prolactin concentrations during treatment, and trials are under way to test this hypothesis.

We thank Dr G V Groom (Cardiff) for the gift of antiserum to prolactin; the NIAMDD for prolactin V-L-S 2; ICI Pharmaceuticals for supplies of Nolvadex and financial support; and Hoechst Pharmaceuticals and Ayerst Laboratories Limited for supplies of LH-RH.

\section{References}

1 Beatson, G T, Lancet, 1896, 2, 104.

2 Lett, H, Lancet, 1905, 1, 227.

${ }^{3}$ Huggins, C, and Bergenstal, D M, Cancer Research, 1952, 12, 134

4 Stoll, B A, Hormonal Management in Breast Cancer. London, Pitmans Medical, 1969.

5 Pearson, O H, and Ray, B S, Cancer, 1959, 12, 85.

${ }^{6}$ Atkins, H J B, et al, Lancet, 1960, 1, 1148.

7 MacDonald, I, fournal of the American Medical Association, 1961, 175, 787.

${ }^{8}$ Bulbrook, R D, et al, Lancet, 1960, 1, 1154.

Atkins, H J B, et al, Lancet, 1968, 2, 1261.

10 Metcalf, M A, fournal of Endocrinology, 1974, 63, 263.

11 Jensen, E V, and Jacobson, H I, Recent Progress in Hormone Research, $1962,18,387$.
12 Toft, D, and Gorski, J, Proceedings of the National Academy of Sciences of the United States of America, 1966, 55, 1574

${ }^{13}$ Lunan, C B, and Klopper, A, Clinical Endocrinology, 1975, 4, 551.

14 Jensen, E V, et al, National Cancer Institute Monograms, 1971, 34, 55.

15 Harper, M J K, and Walpole, A L, Nature, 1966, 212, 87.

16 Cole, M P, et al, British fournal of Cancer, 1971, 25, 270.

17 Ward, H W C, British Medical fournal, 1973, 1, 13.

18 Golder, M P, et al, European fournal of Cancer, 1976, 12, 719.

19 Willis, K J, Fournal of Endocrinology, 1976, 61, 51P.

${ }^{20}$ Shaw, R W, et al, fournal of Obstetrics and Gynaecology of the British Commonwealth, 1974, 81, 632.

21 Glass, M, et al, British fournal of Obstetrics and Gynaecology, 1976, 83, 495.

22 Vekemans, M, and Robyn, C, British Medical fournal, 1975, 4, 738.

23 Duignan, N M, et al, Clinical Endocrinology, 1975, 4, 287.

${ }^{24}$ Czygan, P-J, and Schulz, K D, Gynecologic Investigation, 1972, 3, 126.

${ }^{25}$ Miller, W R, and Forrest, A P M, Lancet, 1974, 2, 866.

${ }^{26}$ Cole, E N, et al, fournal of Endocrinology, 1976, 69, 49P.

27 Wilson, R G, et al, Cancer, 1974, 33, 1325.

${ }^{28}$ Ohgo, S, et al, Cancer, 1976, 37, 1412

29 Robyn, C, and Vekemans, M, Acta endocrinologica, (Kpbenhavn), 1976, $83,9$.

${ }^{30}$ Jacobs, L S, et al, fournal of Clinical Endocrinology and Metabolism, 1973, 36, 1069.

(Accepted 15 December 1976)

\section{SHORT REPORTS}

\section{Steroid cards: patient compliance}

Long-term oral corticosteroid treatment is associated with secondary adrenocortical atrophy. For this reason, each patient on steroids is issued with a card which indicates the nature and dosage of treatment. We have investigated the extent of patient compliance in carrying notification of steroid drug use.

\section{Patients, methods, and results}

One hundred patients, receiving corticosteroid drugs for rheumatoid arthritis, were interviewed. Each patient was asked (1) Do you have a steroid card ? (2) Were you ever issued with a card ? (3) Can you produce your card ? (4) Do you know why you should always carry your card ? The answers to the first three questions were scored on a "Yes" or "No" basis. Evaluation of a correct or incorrect answer to question (4) was made by the interviewer. Eighty-seven patients said that they had cards and 88 agreed that a card had been issued. Seventy-six could produce their cards, while $77 \mathrm{knew}$ why they should be carried. The reasons for the discrepancies in the figures are shown in the table. In 43 cases the dose of drug currently being taken was compared with the dose on the card. Agreement was found on 29 occasions $(67 \%)$ and discordance in 14 instances $(33 \%)$. The mean discrepancy was $2.46 \mathrm{mg}$ prednisolone equivlaent (standard deviation $1.42 \mathrm{mg}$ ).

Breakdown of patients' replies to questioning

\begin{tabular}{|c|c|c|c|c|c|c|c|}
\hline \multicolumn{8}{|c|}{ Do you know why you should always carry your card? } \\
\hline \multicolumn{4}{|c|}{ Yes $(n=77)$} & \multicolumn{4}{|c|}{ No $(n=23)$} \\
\hline \multirow[t]{2}{*}{$\begin{array}{c}\text { Card } \\
\text { produced }\end{array}$} & \multicolumn{3}{|c|}{ Card not produced } & \multirow[t]{2}{*}{$\begin{array}{c}\text { Card } \\
\text { produced }\end{array}$} & \multicolumn{3}{|c|}{ Card not produced } \\
\hline & $\begin{array}{l}\text { Never } \\
\text { issued }\end{array}$ & $\begin{array}{c}\text { At } \\
\text { home }\end{array}$ & Lost & & $\begin{array}{l}\text { Never } \\
\text { issued }\end{array}$ & $\begin{array}{c}\text { At } \\
\text { home }\end{array}$ & Lost \\
\hline 65 & 4 & 8 & 0 & 11 & 8 & 3 & 1 \\
\hline
\end{tabular}

\section{Discussion}

In this survey almost a quarter of patients could not produce notification that they were taking steroid treatment. They must therefore be considered to be at risk of receiving inadequate treatment in an emergency. Half of them claimed that a card had never been issued. It was impossible to verify this. With one exception, the remainder claimed that the cards were at home, although most of them were aware of the necessity to carry the card at all times. Some four subjects who had never received a card appeared to know why they should have one. Overall, only 65 patients could both show a card and explain why it should be carried. The discrepancy between recorded and actual doses in one-third of cases is of more academic than practical importance, since emergency "steroid cover" is an all-or-none phenomenon unrelated to daily dosage. Nevertheless, along with the failure of the patients to produce a card, for whatever reason, it points to a lack of close supervision of potentially hazardous treatment.

During the survey cards were issued to all subjects who were unable to produce one; dosage was updated when necessary; and a full explanation given to each patient about the potential hazards of steroid treatment.

The Clinical Pharmacology Unit gratefully acknowledges the financial support of Roche Products Ltd.

(Accepted 19 September 1976)

Clinical Pharmacology Unit, Royal Bath Hospital, Harrogate, and Rheumatism Research Unit, University Department of Medicine, General Infirmary, Leeds

W W DOWNIE, MB, MRCP, clinical pharmacologist

P A LEATHAM, SRN, research metrologist

V M RHIND, SRN, RSCN, research metrologist

V WRIGHT, MD, FRCP, professor of rheumatology

\section{Simple method for diagnosing protein-losing enteropathies}

Excessive loss of plasma proteins into the gastrointestinal tract occurs in several disorders. Methods currently available for detecting this loss are cumbersome, imprecise, and expensive and entail administering radioactive isotopes and collecting faeces over several days. ${ }^{1}$

$\alpha_{1}$-Antitrypsin, a glycoprotein present in normal serum at a concentration of $1.9-5.0 \mathrm{~g} / \mathrm{l}$, has been measured in meconium from healthy infants and from those with cystic fibrosis. ${ }^{2}$ This protease inhibitor itself appears to be resistant to degradation by gut proteases.

We present evidence that the measurement of $\alpha_{1}$-antitrypsin in a random faecal sample may be used to diagnose protein-losing enteropathy. 